症例

腹部造影 CT にて診断した急性下腸間膜動脈閉塞症の 1 例 弘前大学第 2 外科, 鳴海病院内科*

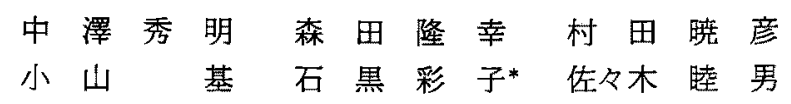

症例は71歳，女性。慢性腎不全のために平成10年より血液透析をうけていた。平成15 年1月 8 日, 軽度の左下腹部痛を訴え, 近医を受診した。急性腸炎疑いとして経過観察 されていたが, 1月10日に腹痛が增悪し,ささらにショック状態に宿ったため, 腹部造影 CT 施行した，CT 画像上, 上腸間膜動静脈は造影されたが,下腸間膜動脈の造影効果が 明らかではなかった、下腸間膜動脈閉塞症を疑診し, 同日, 当科入院となり緊急手術を 施行した，開腹すると，横行結腸中央部から S 状結腸までの左側結腸に, 明らかな腸管 穿孔は認めなかったが高度の壊死性変化を認めた. 触診上, 下腸間膜動脈の拍動は消失 していた. 左半結腸を切除し, 直腸を空置, 横行結腸ストーマ造設術を施行した. 術後, 全身状態は改善していったが, 術後 6 日目に脳梗塞を合併し,さらに術後14日目に急性 心筋梗塞を発症し1月25日死の転帰をとった。

索引用語：急性腸間膜血管閉塞症, 急性下腸間膜動脈閉塞症, 慢性腎不全

\section{緒 言}

急性腸間膜血管閉塞症は特徵的な臨床症状にそしい が，急激に広範囲な腸管の虚血や壊死が発生し，極め て予後不良な疾患のひとつである．高齢者の增加と生 活の欧米化に伴い, 本邦でもその報告例が增加傾向に ある。しかし，その多くは上腸間膜動脈領域の領域で あり, 下腸問膜動脈領域の閉塞は稀である. 今回, 腹 部造影 CTにて診断しえた急性下腸間膜動脈閉塞症 (以下, 本症)の1例経験したので文献的考察を加 えて報告する。

症例：71歳, 女性.
主訴：左下腹部痛.
家族歴：特記事項なし.
既往歴：急性心筋梗塞. 慢性督不全のために平成10 年より透析治療を受けていた。

現病歴: 平成15年 1 月 8 日より左下腹部痛が出現 し, 急性腸炎疑いとして近医に入院した。 1 月9 日激 烈な痛みとなり,ショック状態に宿ったため当院に搬

2004年 1月23日受付 2004年 5 月12日採用 〈所属施設住所〉

干036-8562 弘前市在府町 5
送された。腹部造影 CT を施行し，急性下腸間膜動脈 閉塞症が疑われ，1月10日当科入院となった。

現症: 身長 $145 \mathrm{~cm}$, 体重 $33 \mathrm{~kg}$, 血圧 $156 / 88$, 脈拍 $100 /$ 分, 体温 $36.5^{\circ} \mathrm{C}$. 左下腹部に圧痛を認めたが, 筋性防 御は軽度であった。

入院時検查所見：血液検查では $\mathrm{Hb} 10.0 \mathrm{~g} / \mathrm{dl}$ と軽

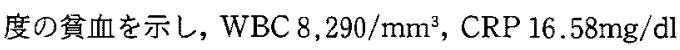
と炎症所見を認め, GOT 203U/l, GPT 24U/l, LDH $637 \mathrm{U} / \mathrm{l}, \mathrm{BUN} 66.4 \mathrm{mg} / \mathrm{dl}, \mathrm{Cr} 7.2 \mathrm{mg} / \mathrm{dl}$ と肝機能, 腎 機能障害を認めた。

腹部 CT 検查 : 上腸間膜動脈根部およびその末梢に は造影効果を認めたが(図 1 a ), 下腸間膜動脈は根部 の一部が造影されるだけで末梢の造影効果は認められ なかった(図 $1 \mathrm{~b})$. 下腸間膜動脈根部付近の大動脈に は著しい石灰化を認めた（図 $1 \mathrm{c}$ )。腹膛内に腫湯, 膿 湯, 腹水, 遊離ガスは認めなかった。血管造影検査は 全身状態が悪化したため施行できなかった。

以上, 腹部所見, 血液検查, 腹部 $\mathrm{CT}$ の結果から下 腸間膜動脈閉塞症と診断し緊急手術を施行した。

手術所見: 開腹時, 左側腹部を中心に, 呩性腹水が 少量貯留し，下行結腸から S 状結腸を中心に腸管が黄 白色から黒色に変色して招り, 虚血による燷死性変化 を認めた。しかし明らかな腸管の穿孔は認めなかった。 


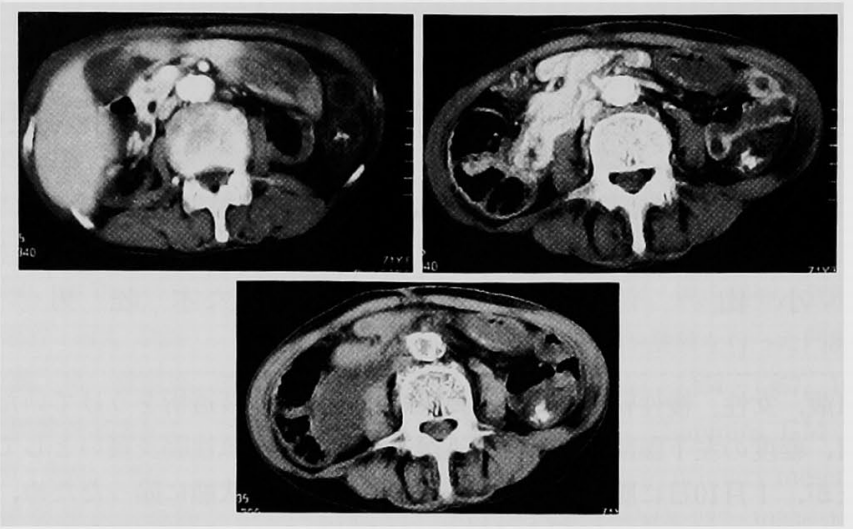

図 1 腹部単純造影 CT 検査： a ) 上腸間膜動脈は造影効果を認めた。

b )下腸間膜動脈および左側結腸の造影効果は明らかでなかった. c)

下腸間膜動脈根部付近の大動脈の石灰化を認めた.

さらに詳しく腹腔内を検索すると腸管の色調変化は口 側では横行結腸中央部まで, 肛門側は岬角まで認めら れた. 下腸間膜動脈根部近辺を触知すると, 拍動は消 失しており, 術前診断どおり下腸間膜動脈閉塞症と診 断した. 術式は左半結腸を切除し, 直腸を空置, 横行 結腸ストーマ造設術を施行した。

切除標本: 横行結腸中央部付近から S 状結腸まて 境界明瞭な腸管の色調変化を伴う腸管壊死所見を認め た. 特に下行結腸では腸管は菲薄化していた. 横行結 腸では腸管の浮腫と粘膜出血が認められた. また下腸 間膜動脈は完全に閉塞していたが, 腸間膜には色調变 化や肉眼的血栓形成はみられなかった。

病理組織所見：切除腸管は全層性にうっ血を認め, 粘膜および粘膜下層は壊死していた。横行結腸は腺細 胞が脱落し虚血性の変化を認めた。下腸間膜動脈切離 端の血管内膜は肥厚していたが血栓は明らかでなかっ た。

術後経過：術後は集中治療室に入室し, CHDF（持 続的血液滤過透析）などの集中治療を開始した，血栓 予防のためにへパリンを 1 日あたり 4,000 単位投与. 呼 吸状態, 循環動態は徐々に改善し, 術後 3 日目に一般 病棟に帰棟した。その後週 3 回の血液透析を再開した。 しかし術後 6 日目に左半身麻癣が出現し, 頭部 CTで 脳梗塞と診断された. その後は, 徐々に全身状態は改 善していき水分摄取も可能となったが, 術後14日目に 突然, 無呼吸, 心室細動の状態に陥った。 心肺蘇生を 実施し一時的に心拍動は出現したが, 術後15日目に永 眠した。
剖検所見：心臓壁は菲薄化し，心筋細胞はほとんど 認めず，硝子化，石灰化を示しており，陳旧性心筋梗 塞の所見であった. また心室中隔には心筋の凝固壊死 と軽度の細胞浸潤が認められ, 急性心筫梗塞の所見を 認めた. 大動脈は粘液様変化, 石灰化, コレステロー ル裂隙, 弾性板の断裂などの熪状硬化を認め, 特に下 腸間膜動脈根部付近ではそれが顕著であった．腎葴は 糸球体がわずかで, end-stage kidney の状態であっ た. 肝蔵は小葉中心性のうっ血, 肝細胞萎縮を認めた。 肺は斑点状に絨維化を認めた。 以上より直接死因は急 性心筋梗塞と診断された。

$$
\text { 考 察 }
$$

急性腸間膜動脈閉塞症は腸間膜血管に急性閉塞性変 化を生じ, その結果, 支配領域の腸管の浮腫, 出血, 壊死などの虚血性変化とそれに伴う重篤な病態をきた す疾患である.

原因として血栓と塞栓にわけられ, 前者は動脈硬化 症, 開腹術後や腹部外傷後に発生しやすく, 後者は弁 膜性心疾患, 心房細動に併発しやすい.

好発部位は上腸間膜動脈領域が圧倒的に多い。この 理由として上腸間膜動脈は広い口径を持って大動脈か ら分岐するのに対して下腸間膜動脈は中結腸動脈およ び内腸骨動脈との間に吻合があり十分な側副血行路に より梗塞が起こりにくいためといわれている゙.

本邦での本症の報告例は少なく1985年以降医学中央 雑誌で検索しえた本症は自験例を含め31例であった

(表 1 ). 本邦の報告例をまとめると年龄は平均71.4歳 と高齢者に多く，そのうち男性が $70 \%$ あっった。基礎 


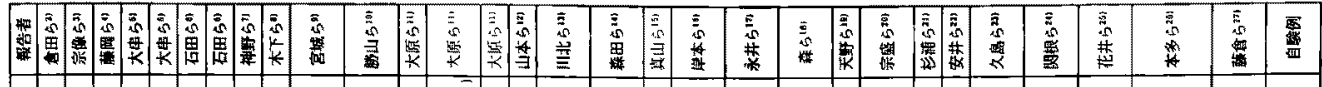

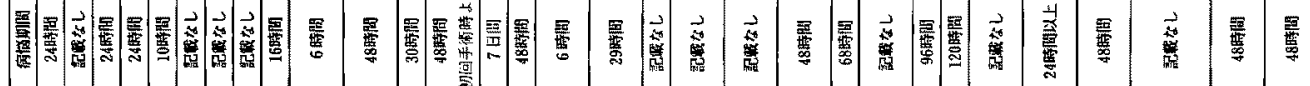

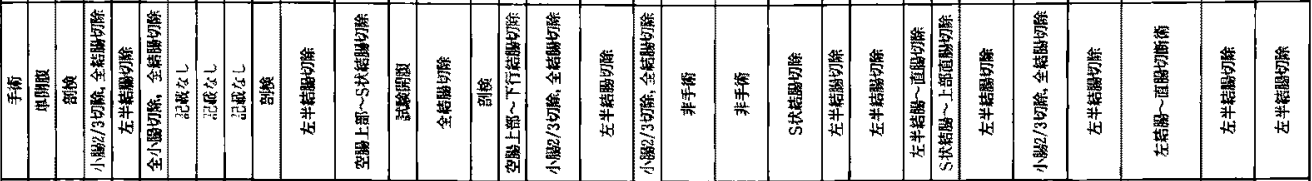

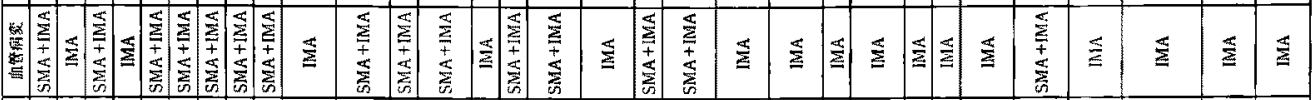

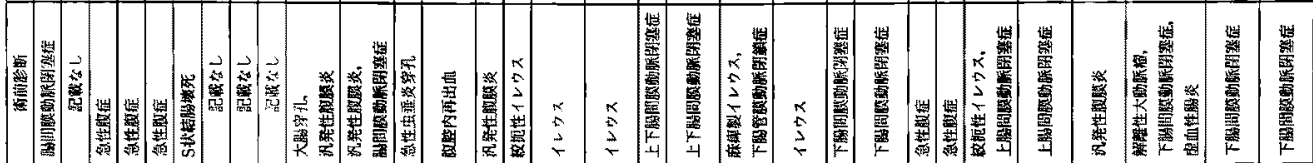

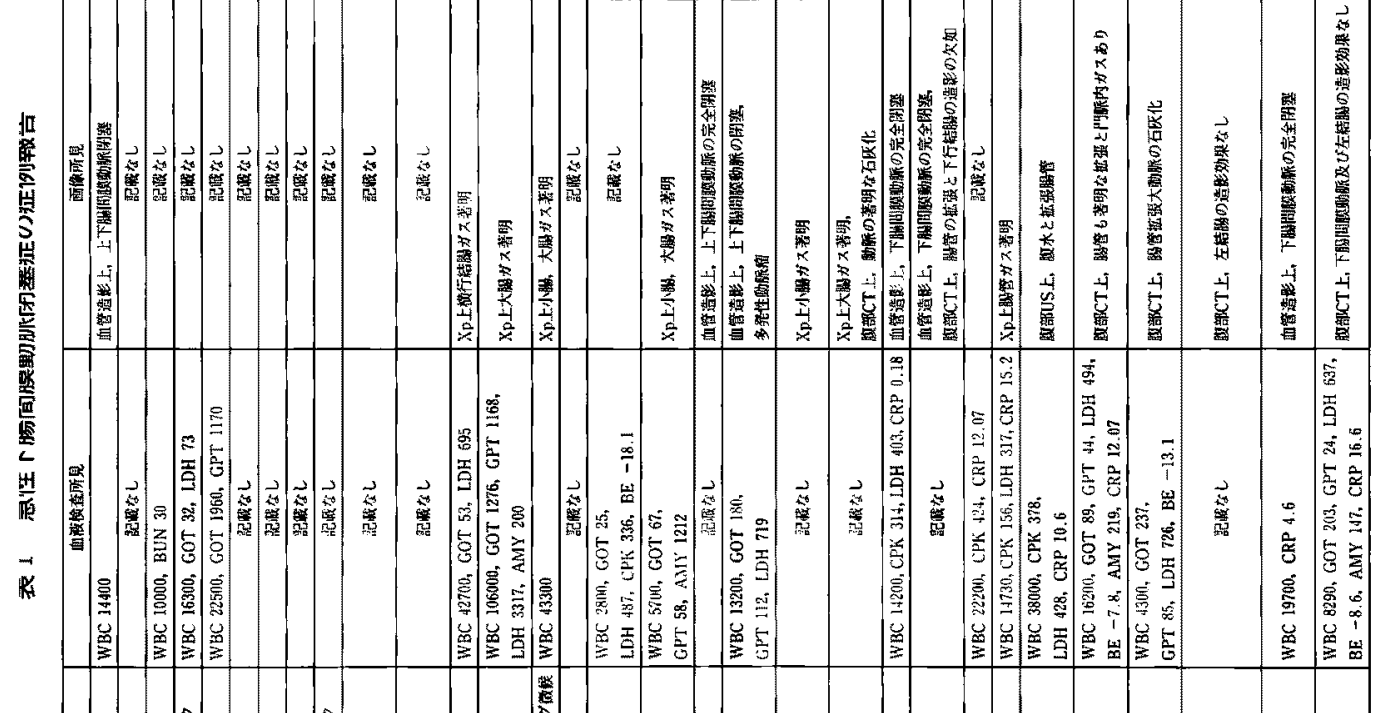

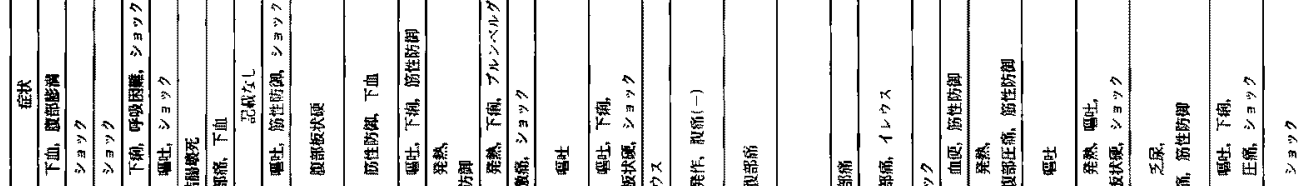

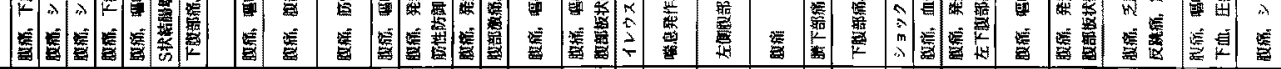

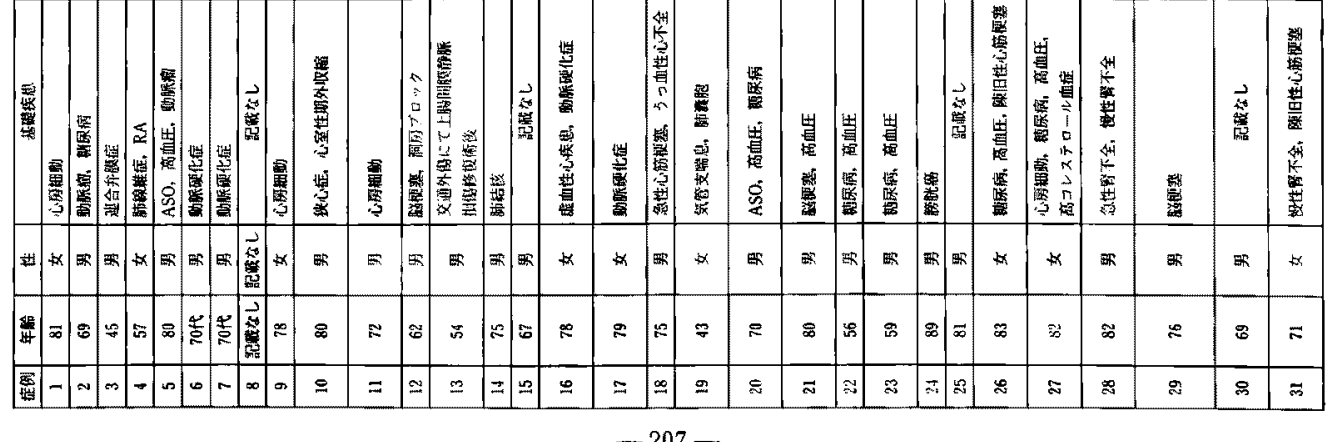


疾㭧としては心血管系がもっとも多く $(75 \%)$ ，ついで 糖尿病であった $(21.4 \%)$ 。自験例では心筋梗塞の既往 があり，慢性腎不全も合併していた。

症状としては腹痛が最も多く(86.7\%)，また術前に ショック状態にまで楩った症例を11例認めた〈36.7 \%)。その他の症状として, 嘔吐, 下痢, 下血などを認 めた。自験例では初期の段階では腹痛のみで他の症状 は認めなかったが,最終的にはショック状態に陥った。 血液検查所見で注白血球, CK, GOT, GPT, LDH, ときにアミラーゼなどが上昇し, $\mathrm{PaCO}_{2}, \mathrm{BE}$ の低下と 代謝性アシドーシスを認めることが多いとされている が28), 記載のあった18例中15例で白血球増加または減 少を認めた。自験例でも白血球增加などの炎症所見, 肝機能障害を認めた。

画像診断では腹部単純 $\mathrm{X}$ 線写真, 腹部 CTに上る麻 痺性イレウス像, 腸管壁の肥厚像などを認めるが, 造 影 CT や血管造影に上る診断が必要である。しかし本 邦報告例では血管造影で下腸間膜動脈の閉塞像を認 め, 正診が得られた例は 6 例であった。その他は他疾 患疑いで手術が施行された。自験例では激烈な腹痛出 現時㳊腹部造影 CT を施行し, その結果, 下腸問膜動 眽閉塞症と診断して手術を施行した。ただし全身状態 が不良のため血管造影は施行できなかった。

治療は大半の症例て左半結腸以上にわたる広範囲の 切除術が施行されていた，保存療法として全身の抗凝 固療法, 閉塞動脈への血栓溶解醉素剂 ${ }^{299}$, 血管拡張郕療 法融などもあるが，確定診断の遅れのなどのために大 部分の例行外科的治療が必要となっている。術式とし て, 血行再建，血栓除去などの血管外科的手技もある が，手術時には腸管が広範囲にわたって壊死している 例がほとんどである. 本邦報告例のうち $82.6 \%$ の症例 は開腹時にすでに広範な腸管壊死を伴っており自験例 も手術時に横行結腸から S 状結腸まで, 広籍囲にわた る腸管切除が必要であった。

病悩期間みると $80 \%$ 以上の症例で 24 時間以上経過 していた。これは急性上腸間膜動脈閉塞症に比べ長い 傾向にある.それは解剖学的に下腸間膜動脈は口径が 狭く, 大動脈に对して鈍角に分肢しているため, 塞拴 よりも血栓が原因となるため血流低下から虚血に至る までの時間が長いためと言われている25). 自験例でも 軽度の腹痛で発症し, 完全虚血の状版になってからシ ヨックを伴う激烈な腹痛に移行した。

予後に関して，死亡率は $35 \%$ と不良である。その原 因として高路者が多いこと，基礎疾患として心血管系
疾患の併存が多いこと, 初期には腹部症状がそしく確 定䛦断が達れること，などが挙げられる。

自験例の成因について考察すると，以前から慢性腎 不全に罹患しておる゙り，術前の心エコーによる評価では 広範囲な陳旧性心筋梗塞，またかなり重篤な僧房弁閉 鎖不全，三尖弁閉鎖不全などを認めた。また心駆出率 は26.9\%と心機能の低下がみられていた，腹部 CT おる よび術中所見では大動眽の広範囲にわたる石死化，と くに下腸間膜動脈分岐部付近で顕著であった。 また解 剖所見でも, 大動脈は粘液様変化, 石灰化, コレステ ロール裂陵, 弾性板の断裂などの粺状硬化が顕著であ った.このように，心血管系に重篤な基礎疾患をもっ ていたために今回のようは結果がもたらされたと思わ れる。

以上より本症は極めて予後不良の急性腹症であり, 心血管系の基礎突患を有する高齢者においては稀ては あるが念頭においた診断, 治療が必要である.

\section{結 語}

腹部造影 CTにて㟝断しえた急性下腸間膜動脈閉塞 症の報告を行った。本症は極めて予後不良であり，救 命には早期診断，早期治療が不可欠である。

\section{文 献}

1) Karmody AM, Jordan FR, Zaman SN : Left colon gangrene after acute inferior mesenteric artery occulusion. Arch Surg 111 : 972-975, 1976

2）倉田 悟, 野島真治, 本楖 碩他：急性腸間膜動脈 閉塞症の治療. Med Postgrad 23：484-489, 1985

3）宗像康博, 萩原迪彦, 林 四郎他: 腸管梗塞症の 治療一臨床的・実駼的考察. 腹部救急診療の進步 $6: 77-82,1986$

4）藤岡䫓太郎, 大原正已，毛利 平他：腸間膜血管 閉塞症に対する手術成績。腹部救急診療の進歩 $6: 99-101,1986$

5）大串直太, 池田知宏, 恒川謙吾他：急性腸間膜動脈 閉塞症. 腹部救急猃璙の進歩 $6: 145-149,1986$

6）石田 徽, 山内正信, 長見睛彦他: 下腸間膜動脈 閉塞症の 2 例. 鳥取医誌 $14: 201 ， 1986$

7) 神野禎次, 松田勇人, 小林一郎：急性下腸間膜動 脈閉塞症の一例。日農村医会誌 $36: 51,1987$

8）木下欣也, 津田知宏, 片場善明他：腸間膜動脈閉 塞症 4 例の検討. 日救急医会関東誌 $9: 250-$ 251,1988

9）裳城道夫, 屋良敏雄, 龟田陽一他: 腸間膜動脈閉 塞症の 2 例纪ついて。沖縄医会誌 $26: 62-63$, 1989

10）勝山和彦, 藤村昌樹, 森渥視他：急性上・下腸 間膜動眽閉塞淀の 1 救命例. 日蹦外会誌 50 ： 1879, 1989

11）大原昌樹, 洲脇谨一郎，今井正信他：当院におり 
る急性腸間膜動脈閉塞症 7 例の梭討．三豊䋓合病 誌 $10: 55-62,1989$

12）山本 明, 藤村昌樹, 平野正満他：上, 下腸開膜 動脈閉塞症による大量腸管切除の 1 例. 消化と吸 取 $12: 105-108,1990$

13）川北直人, 襄川公章, 植松 清他: 急性腸閥膜動 眽閉塞症 7 例の检討. 日消外会誌 $23: 1159-$ 1163,1990

14）森田章夫, 岩本 忠, 高田孝好他：急性下腸間膜 動脈閉塞症の1例. 日臨外会誌 $53: 2181-2185$, 1992

15）真山 崇, 原田迅明, 大原元太他：心筋梗塞急性 期に合併した上・下腸問膜動脈閉塞症の麻酔経験。 麻酥 $42: 1393,1993$

16）岸本卓已, 岡原正莘, 小崎 珰司他：気管支喘息 経過中に上下腸間膜動眽閉塞症を合併した多発性 動脈瘤・門脈瘤の1例. アレルギーの臨 $16: 670$ $-675,1996$

17) 永井 隆, 石川武志, 永井洋子他: 下腸間膜動脈 閉塞症を併発し救命し得た䌅尿病の1例. 日内会 関東会抄集 $7: 158,1996$

18）森 玩磨, 熊本吉一，片山清文詣：急性下腸間膜 動腺閉塞症 01 例. 神奈川医会誌 $23: 258,1996$

19）天野票啺，藤湘正彦，正岡哲也他：術前猃断によ り救命しえた急性下腸間膜動脈閉塞症の 1 列。日 腹部救急医会誌 $17: 145,1997$

20）宗盛 真, 森島信行, 本藤達也他: 下胆䦨膜動脈 閉塞症の1例. 広島医 $50: 603,1997$

21）杉浦良啓, 武田明子, 斉藤律子他：急性腸間膜動
目瓜閉塞症の麻酔管理の検討. 蘇生 $17: 125-128$, 1998

22）安井祐司, 迎山恭吾, 大薮久則：下腸間膜動脈䦎 塞症の 1 例。日腹部救急医会誌 $20: 366,2000$

23）久島昭浩, 川崎紀草, 高橋雅哉他: 下腸間膜動脈 閉塞症の 1 例. 日臨外会誌 $61: 2841,2000$

24）関根祐樹，北村道彦：門脈がス血栓を合併した急 性上・下腸間膜動脈閉塞症の1例. 日腹部救急医 会誌 $21: 743-746,2001$

25）花井雅志, 井垣 啓, 青野景也他：急性下腸開膜 動脈閉塞症O1例。日臨外会誌 $63: 1208-1211$, 2002

26）本多桂, 太田信次, 藤岡重一他: 急性下腸間膜 動脈閉塞症の 1 例. 日塸外会誌 63 (增刊号)： 386,2002

27）藤倉博之, 岩本末治, 山下和城他：急性下腸間膜 動脈閉塞症の 1 例. 日腹部救急医会誌 $22 ： 475$, 2002

28）石橋宏之, 蜂須賀喜多男, 原川伊寿他: 急性上腸 間膜動脈閉塞症の臨床的検討. 腹部救急診療の進 檚 $6: 139-144,1986$

29) Flickinger $E$, Johnsrude I, Ogburn $N$, et al: Local streptokinase infusion for superior mesenteric artery thromboembolism. Am J Radiol $140: 771-772,1983$

30) Clark R, Gallant T: Acute mesenteric ischemia : Angiographic spectrum. Am J Radiol $142: 555-562,1984$

\title{
ACUTE OBSTRUCTION OF THE INFERIOR MESENTERIC ARTERY DIAGNOSED BY ENHANCED ABDOMINAL CT SCAN-REPORT OF A CASE-
}

\author{
Hideaki NAKAZAWA, Takayuki MORITA, Akihiko MURATA, \\ Motoi KOYAMA, Ayako ISHIGURO* and Mutsuo SASAKI \\ Second Department of Surgery, Hirosaki University School of Medicine \\ *Department of Internal Medicine, Narumi Hospital
}

A 71-year-old woman who had been on hemodialysis for chronic renal failure since 1998 visited another hospital because of mild left lower abdominal pain on January 8,2003 . She was followed with a suspicion of acute enteritis until January 10 , when the abdominal pain was aggravated and then she went into shock. On enhanced abdominal CT scan conducted at the hospital visualized superior mesenteric vein but enhancement effect for the inferior mesenteric artery was obscure. She was admitted to the hospital with a suspicion of obstruction of the inferior mesenteric artery, and underwent surgery on the same day. At laparotomy no prominent intestinal perforation was present on the left colon covering from the center of the transverse colon to the sigmoid colon, but severe necrotic change was noted. On palpation, pulsation of the inferior mesenteric artery disappeared. Left hemicolectomy was performed, interposition of the rectum was carried out, and a stoma was constructed on the transverse colon. After the operation the patient's general condition became stable, however, she developed cerebral infarction on the sixth and acute myocardial infarction on the $14^{\text {th }}$ postoperative day, and died on January 25 . 